\title{
Evaluation of asthma course in pregnancy
}

\author{
Agnieszka Rey, Ewa Jassem, Marta Chelminska \\ Allergology Department, Medical University of Gdansk, Poland
}

\begin{abstract}
The prevalence of asthma has been rising in recent decades. It is the most common disease among pregnant women and affects ca. $12 \%$ of this population. The course of asthma in pregnancy may change. In $1 / 3$ of patients, it worsens; in $1 / 3$ of patients, the symptoms are milder; in $1 / 3$ of patients, it remains unchanged. Well-controlled asthma decreases the risk of pregnancy complications. Uncontrolled and severe asthma increases the risk of congenital malformations and obstetrical complications for both mother and baby. Exacerbations may also contribute to poor pregnancy outcomes. These occur mostly either in the first or in the second trimester. The most common triggers are viral infections and treatment non-compliance. The key to maintaining and gaining control of asthma is active treatment of asthma and its exacerbations.
\end{abstract}

Key words: asthma; pregnancy; asthma exacerbations; asthma treatment; asthma diagnosis

Ginekologia Polska 2019; 90, 8: 464-469

\section{INTRODUCTION}

The prevalence of allergic diseases and asthma has been rising in recent decades, reaching $5 \%$ of the adult, and $10 \%$ of the child and teenage population in Poland. Asthma is the most common disease complicating pregnancy, which affects $12 \%$ of pregnant women [1], and may lead to poor maternal and neonatal outcomes, especially in severe, uncontrolled, or inappropriately managed cases [2]. Likewise, pregnancy, by leading to multiple changes in the organism, influences the course of asthma. It is believed that the course of asthma during pregnancy improves in approximately one third of patients, in one third the course of the disease remains stable, and in one third it worsens. Worsening usually affects patients with uncontrolled and severe asthma, however it can also occur in patients with well-controlled symptoms [3]. Pregnant women with asthma need multidisciplinary and careful management.

The aim of this study is to summarize current knowledge on the bilateral relationship between asthma and pregnancy, and to sum up any recommendations concerning the management of asthma in pregnancy, as this remains a challenge in many aspects.

The possible influence of physiological pregnancy changes on the course of asthma

Developing pregnancy triggers many adaptive changes in the organism. Changes in the anatomical, hormonal, and immune system are particularly important for the control of asthma.

Anatomical changes in physiological pregnancy include: edema, increased vascularity in the upper respiratory tract, mucosa, and bronchodilation. The diaphragm is displaced, leading to changes in breathing, from a respiratory to abdominal pattern. Tidal volume (TV) and inspiratory capacity (IC) increase, while functional residual capacity (FCR), total lung capacity (TLC) and vital capacity (VC) decrease during the course of pregnancy. Forced expiratory volume in one second (FEV1), peak expiratory flow (PEF) and airway resistance remain unchanged $[4,5]$.

Other changes in the respiratory tract include an increase in the respiratory rate and oxygen consumption (for approximately 20\%). Eventually, $\mathrm{PaO}_{2}$ (partial pressure of oxygen) increases to the values $100-105 \mathrm{~mm} \mathrm{Hg}$, $\mathrm{PCO}_{2}$ (partial pressure of carbon dioxide) decreases to the values $27-32 \mathrm{~mm} \mathrm{Hg}$. The resulting alkalosis leads to renal loss of bicarbonates and to a decrease of bicarbonates blood concentrations to the values between $18-21 \mathrm{mEq} / \mathrm{L}$ (Tab. 1). Even a small rise in $\mathrm{pCO}_{2}$ concentrations (above $35 \mathrm{~mm} \mathrm{Hg}$ ) may indicate respiratory failure and may lead to fetal acidosis. A decrease in $\mathrm{PaO}_{2}$ concentration below $70 \mathrm{~mm} \mathrm{Hg}$, indicates maternal hypoxemia and may also lead to fetal hypoxemia [4,5].

Pregnancy leads to intensive hormonal changes. The blood concentration of many hormones rises. A two-fold change is observed in cortisol, a nine-fold change in pro- 
Table 1. Reference ranges for arterial blood gases in pregnancy [5]

\begin{tabular}{|l|l|}
\hline Investigations & Pregnant \\
\hline $\mathrm{pH}$ & $7.40-7.45$ \\
\hline $\mathrm{pCO}_{2}{ }^{2} \mathrm{mmHg}$ & $27-32$ \\
\hline $\mathrm{pO}_{2}{ }^{1} \mathrm{mmHg}$ & $100-105$ \\
\hline Base excess & No change \\
\hline Bicarbonate $(\mathrm{mmol} / \mathrm{l})$ & $18-21$ \\
\hline Saturation & $95-98 \%$ \\
\hline
\end{tabular}

${ }^{1} \mathrm{~Pa} \mathrm{O}_{2}$ partial pressure of oxygen; ${ }^{2} \mathrm{PaCO}_{2}$ partial pressure of carbon dioxide

gesterone, and a 100-1,000 fold in estrogenes serum concentration. The increase in cortisol and progesterone should potentially lead to bronchodilatation; however, due to the competitive affinity of the above-mentioned hormones to the glucocorticoids receptor, the effect may be limited [5, 6].

Immunological changes in lymphocyte proportions during pregnancy, described as $\mathrm{Th}_{2}$ domination, may predispose to asthma exacerbations [5, 7]. Moreover, to prevent a maternal response to fetal antigens, the concentration of Th regulatory cells increases. This state results in decreased activation of effector lymphocytes T and natural killers (NK), which, in turn, leads to immunosuppression [7]. This increases susceptibility to viral infections and elevates the risk of possible complications if infection occurs [6]. One of the studies confirmed that the co-existence of asthma and pregnancy may predispose respiratory and urinary tract infections [8].

\section{The influence of asthma on the course of pregnancy}

Correspondingly, asthma may influence the course of pregnancy in numerous ways.

An association between asthma and gestational diabetes, perinatal hemorrhage, placental defects [2], pre-eclampsia [9], and congenital defectsincluding cleftpalateand gastroschisis[10], have been confirmed in several meta-analyses. Some studies indicated a risk of cesarean section [2], preterm birth [11], low birth weight, longer hospitalization of the newborn and even newborn death [12]. Possible mechanism of mentioned complications include hypoxia, maternal inflammation, changed uterine smooth muscle relaxation, reduction of placental 11 beta hydroxysteroid dehydrogenase enzyme and drug (mainly betamimetics) influence $[10,11]$, and is mostly linked with exacerbations [11]. Many authors and guidelines suggest that the complications may be prevented if appropriate effective treatment is used $[11,13]$. The latter was confirmed in research from recent years, in which women with diagnosed asthma were enrolled in the programme before 18 week of gestation and obtained active management. This consisted of monthly visits with objective assessment, including spirometry, fractional exhaled nitric oxide (FENO) and the adjustment of medication. A reduction in the prevalence of uncontrolled asthma of $80 \%$ was observed. Achieving good asthma control prevented most of the previously mentioned complications. However, the study confirmed that a small, but significantly higher, risk of pre-eclampsia and small for gestational age (SGA) is associated with asthma, despite good control [3]. The risk of SGA increases with increased asthma severity.

\section{Diagnostic tests in pregnancy}

Proper diagnosis and evaluation of asthma control is crucial, particularly during pregnancy. General approach to asthma diagnose in pregnancy is the same as in non-pregnant patients. Tests generating a risk of pregnancy complications (provocation tests and skin prick tests) are contraindicated during the whole course of pregnancy [4]. Acceptable tests are shown in a Table 2. Lung function tests are considered to be safe during pregnancy. Interpretation may be difficult, especially during the third trimester of pregnancy [14], due to associated physiological changes. One recent study demonstrated moderate changes in the pulmonary function. FEV1 declined significantly in second semester (mean $139 \mathrm{~mL}$ ), then improved significantly in the last weeks of gestation (mean $51 \mathrm{~mL}$ higher to baseline). FVC and FEV6 changed insignificantly. Authors suggest that FEV6 may be used in asthma monitoring during pregnancy as it correlated positively with FVC. Nevertheless, changes in pulmonary function were not significantly associated with changes in asthma control [15]. PEF remains a valuable test during pregnancy. It should range between 380-550 L/min, but each asthmatic individual needs to establish his or her best effort. Maintaining levels $>90 \%$ of personal best value is considered optimal control [4]. Contraindications

\begin{tabular}{|c|c|c|}
\hline $\begin{array}{l}\text { Diagnostic tools } \\
\text { in pregnancy }\end{array}$ & Remarks & Contradictions \\
\hline PEF & $\begin{array}{l}\text { useful/no changes, normal } \\
\text { values described in the text }\end{array}$ & $\begin{array}{l}\text { pre-eclampsia, } \\
\text { cervix } \\
\text { insufficiency }\end{array}$ \\
\hline Spirometry & $\begin{array}{l}\text { useful, problematic } \\
\text { evaluation in advanced } \\
\text { pregnancy, }\end{array}$ & $\begin{array}{l}\text { pre-eclampsia, } \\
\text { cervix } \\
\text { insufficiency }\end{array}$ \\
\hline FENO & useful & $\begin{array}{l}\text { no } \\
\text { contraindications }\end{array}$ \\
\hline Blood gases & changes in normal values & $\begin{array}{l}\text { no } \\
\text { contraindications }\end{array}$ \\
\hline Oximetry & changes in normal values & $\begin{array}{l}\text { no } \\
\text { contraindications }\end{array}$ \\
\hline $\begin{array}{l}\text { Provocation } \\
\text { tests }\end{array}$ & - & $\begin{array}{l}\text { generally } \\
\text { contraindicated }\end{array}$ \\
\hline SPT, ICT & - & $\begin{array}{l}\text { generally } \\
\text { contraindicated }\end{array}$ \\
\hline
\end{tabular}


Table 3. Main points for good asthma management in pregnancy on the basis of a GINA report [13]

- Active asthma treatment outweighs the potential risk of medication use (evidence $\mathbf{A}$ )

- Use of available medication to achieve good symptom control and prevent exacerbation is justified, even if the safety is not completely proven (evidence $\mathbf{A}$ )

- Cessation of ICS is a risk factor for exacerbations (evidence A)

- Reduction of treatment is not recommended (evidence D)

- Educational resources for patients

- Monthly monitoring is recommended

- Monitoring and proper management of respiratory infections

- Early treatment of exacerbations with $S A B A$, oxygen and systemic GCS is recommended

ICS - inhaled glucocorticosteroids; GCS - glucocorticoseroids; $\mathrm{SABA}$ - short acting betamimetics

for lung function testing include cervix insufficiency and pre-eclampsia [14].

Furthermore, the FENO test was found to be a useful diagnostic tool, and was proven to help in gaining asthma control, if used with monthly control [16]. Moreover, multidisciplinary management [14] and asthma control test were also proven to be useful during pregnancy. The latter test correlates well with actual asthma control.

\section{Asthma treatment in pregnancy, peripartum and lactation \\ Pregnancy}

Despite constant concern about medication safety in pregnancy, asthma treatment is generally consid-

\begin{tabular}{|l|l|}
\hline Table 4. Treatment of asthma in pregnancy [1, 13] \\
\hline Step 1 & $\begin{array}{l}\text { ICS (small dose)* } \\
\text { or none }\end{array}$ \\
\hline Step 2 & $\begin{array}{l}\text { ICS (small dose)* } \\
\text { or LTRA* } \\
\text { or theophylline }\end{array}$ \\
\hline Step 3 & $\begin{array}{l}\text { ICS (small dose) + LABA* } \\
\text { or ICS (medium dose)* } \\
\text { or ICS (high dose)* } \\
\text { or ICS small dose + LTRA* } \\
\text { or ICS small dose + teophylline }\end{array}$ \\
\hline Step 4 & $\begin{array}{l}\text { ICS (medium or high dose) + LABA* } \\
\text { ICS high dose + LTRA* } \\
\text { ICS high dose + theophylline } \\
\text { add tiotropium }\end{array}$ \\
\hline Step 5 & $\begin{array}{l}\text { Higher lever care* } \\
\text { oral glucocorticost eroids* } \\
\text { add tiotropium }\end{array}$ \\
\hline
\end{tabular}

*Emboldened text suggests more suitable therapeutic option in pregnancy

ered safe. Principals are adequate to those concerning non-pregnant patients (Tab. 3, Tab. 4). The authors agree that the treatment must be intensified if asthma control is insufficient, as complications of undertreated asthma markedly exceed the possible, but not fully proven, side effects of the treatment (Tab. 5). The basis of treatment are inhaled glucocorticoids (ICS). Other drugs including ipratropium, leukotriene receptor antagonists (LTRA), short and long acting betamimetics (SABA, LABA), systemic glucocorticosteroids and omalizumab are also accepted in treatment, particularly in partly and uncontrolled asthma. Theophylline is not recommended to be used in pregnancy due to possible side effects. There is no

\begin{tabular}{|c|c|c|c|c|c|}
\hline Treatment in pregnancy & $\begin{array}{l}\text { Former FDA } \\
\text { class }\end{array}$ & $\begin{array}{l}\text { Possible side } \\
\text { effects }\end{array}$ & $\begin{array}{l}\text { Studies confirming } \\
\text { occurrence of } \\
\text { malformations }\end{array}$ & Remarks & $\begin{array}{l}\text { Studies } \\
\text { confirming } \\
\text { safety of drugs }\end{array}$ \\
\hline Betamimetics & C & $\begin{array}{l}\text { Cleft lip } \\
\text { and palate, } \\
\text { omphalocele }\end{array}$ & Garne [10] & $\begin{array}{l}\text { Meta-analysis of Eltonsy } \\
\text { indicates defects both in studies } \\
\text { concluding on safety and those } \\
\text { asserting side effects of the } \\
\text { treatment [17] }\end{array}$ & Eltonsy [18] \\
\hline Inhaled Glucocorticosteroids & $\mathrm{B} / \mathrm{C}$ & $\begin{array}{l}\text { Musculoskeletal } \\
\text { and heart defect } \\
\text { for large doses }\end{array}$ & Blais [19] & $\begin{array}{l}\text { Defects confirmed only for } \\
\text { large doses of inhaled GCS }\end{array}$ & Garne [10] \\
\hline Systemic glucocorticosteroids & C & $\begin{array}{l}\text { Preterm birth, } \\
\text { low birth weight, } \\
\text { pre-eclampsia }\end{array}$ & Gregersen [20] & $\begin{array}{l}\text { Mentioned findings should be } \\
\text { balanced against severe asthma } \\
\text { control }\end{array}$ & - \\
\hline Antileukotriens & B & No connection & - & Short observation period & Bakhireva [21] \\
\hline Antimuscarinic agents & B (ipratropium) & - & - & - & - \\
\hline Omalizumab & B & No connection & - & Short observation perriod & Namazy [22] \\
\hline Mepolizumab & - & - & - & - & - \\
\hline
\end{tabular}

ISC — inhaled glucocorticosteroids; LABA — long acting betamimetics; LTRA — acting betamimetics 
sufficient data concerning tiotropium and mepolizumab in pregnancy.

Although guidelines on asthma treatment are easily accessible, most studies confirm a tendency to reduce treatment in pregnant women.

Up to $40 \%$ of patients declared to give up treatment after getting pregnant without consultation with a doctor [6]. The declarations mentioned may be partly confirmed by a Dutch study using a large database, comprising of detailed data on prescriptions. It shows a clear tendency for a reduction in the number of prescriptions issued after a diagnosis of pregnancy, which may indicate a decline in treatment after getting pregnant. This phenomenon may partly be the result of a milder course of asthma during pregnancy [23]. In addition, the problem of under-treatment is related to medical personnel, as pregnant asthmatics were significantly less likely to be given oral steroids, either in the emergency department or on discharge from hospital, than non-pregnant women [9], regardless of recommendations and results of studies that concluded on the relative safety of systemic GCS use for asthma exacerbations [12]. In the study cited, the use of systemic GCS was not related to poor perinatal outcomes, except for an increases rate of caesarean delivery.

Proper education on the treatment and safety of both patients and physicians may play an essential role in the improvement of asthma treatment during pregnancy.

\section{Peripartum}

Although exacerbations of asthma in peripartum period are rare, regular treatment should be maintained to avoid exacerbations. Hyperventilation [13] and drugs indicated due to obstetric and anesthetic management of labour may influence asthma and cause bronchospasm [24]. Short acting betamimetics are drugs of choice for peripartum bronchospasm $[4,13]$. Neonates require blood glucose control for the subsequent 48 hours after exposure to excessive doses of mentioned drugs, to detect possible hypoglycemia [13]. Specification and safety of the most frequently used drugs in peripartum period is enclosed in Table 6 .

\section{Breastfeeding}

Although studies concerning safety of anti-asthmatic drugs are limited, most of the drug groups are considered safe in lactation. For inhaled glucocorticosteroids (budesonide, fluticasone) infant exposure is far below the therapeutic level for an infant. Available in vitro studies for ciclesonide predict undetectable exposure of infant [25]. Inhaled betamimetics are accepted during breastfeeding as their concentrations in mothers' blood remain low. $[25,26]$. Antileukotrienes, anticholinergic agents and omalizumab are accepted if necessary for asthma control and the excretion into milk or bioavailability (omalizumab) is suggested to be minimal [27]. Among oral glucocorticosteroids prednisolone is preferred to avoid double peak of parent medicine and

\begin{tabular}{|c|c|c|}
\hline Group of drugs & Drugs safe in asthma & Drugs contraindicated in asthma \\
\hline Induction of labour & $\begin{array}{l}\text { In some cases drugs may be administered with } \\
\text { caution eg. oxytocin }\end{array}$ & generally contraindicated \\
\hline Analgesia & $\begin{array}{l}\text { opioids administered with caution (risk of } \\
\text { bronchoconstriction) }\end{array}$ & $\begin{array}{l}\text { contraindicated in actively wheezing patient and in } \\
\text { respiratory distress }\end{array}$ \\
\hline \multicolumn{3}{|l|}{ Anestesia } \\
\hline \multirow[t]{2}{*}{ Epidural anesthesia } & opioids & \\
\hline & local anestetics & $\begin{array}{l}\text { avoid high and dense level of anesthesia due to } \\
\text { possible impairment of accessory respiratory muscles }\end{array}$ \\
\hline General anastesia & only if regional anesthesia is contraindicated & \\
\hline \multirow[t]{2}{*}{ Intravenous } & ketamine & \\
\hline & propofol & \\
\hline \multirow[t]{2}{*}{ Volatile halogenated agents } & isoflurane & \\
\hline & sevoflurane & \\
\hline \multirow[t]{3}{*}{ Miorelaxants } & pancuronium & atracurium \\
\hline & cis-atracurium & \\
\hline & rocuronium & \\
\hline \multirow[t]{2}{*}{ Other treatment } & & betablockers \\
\hline & & ergot alkaloids \\
\hline
\end{tabular}


metabolite. The amount of drug excreted in milk remains low up to dose $80 \mathrm{mg}$ [25].

\section{Patophysiological factors influencing the course of asthma during pregnancy Exacerbations}

Exacerbations of asthma during pregnancy represent a significant problem that may lead to unfavourable pregnancy outcomes. About 5 to $20 \%$ of asthmatic pregnant women require medical intervention due to the occurrence of exacerbations of asthma during pregnancy [9]. It has been suggested that well-controlled asthma, together with no history of previous exacerbations and no prescribed controller medication, is associated with a lower risk of exacerbations during pregnancy [28]; however, these may occur in up to $37 \%$ of pregnancies complicated by well-controlled asthma, and $40 \%$ of these exacerbations may be severe [3].

In most of the studies, exacerbations occurred in the second trimester of pregnancy [9]. However, in one recent study, exacerbations were detected most frequently during the first trimester of pregnancy [3]. Moreover, Blais et al. [29] confirmed the risk of congenital malformation and its association with exacerbations in 19\% in of pregnancies during the first trimester. These findings may indicate a need for the intensification of treatment and management of asthma preconceptionally.

The most important trigger of exacerbations are infections, to which pregnant women are more susceptible due to adaptive changes in the immune system. Respiratory tract infections are the most frequent of these [8]. It was also confirmed that both pregnancy and asthma raise the risk of AH1N1 influenza [30]. Furthermore, influenza vaccination in pregnant asthmatics increased the improvement of the condition by $50 \%$, in comparison with $15 \%$ in the patients who had not been vaccinated [31].

Another important factor for exacerbations is lack of treatment compliance [9]. Further factors include inadequate prenatal care, lack of or inappropriate GCS treatment, and smoking [6].

Some authors consider obesity and excessive weight gain in pregnancy a risk factor for the exacerbation of asthma in pregnancy. Furthermore, an increased risk of gestational diabetes has been noticed in the group of patients with the co-morbidities of asthma and obesity [6].

The occurrence of severe exacerbations creates a risk of pre-term birth, small for gestational age [6] and pre-eclampsia [3, 6].

\section{Toxins and allergens exposure}

Smoking, both active and passive, is an underestimated factor influencing the course of asthma during pregnancy. About $15 \%$ of pregnant women are active smokers [32];

\section{Table 7. Side effect of smoking in pregnancy}

- placenta previa

- abruptio placentae

- premature rupture of the membranes,

- pre-term birth

- intrauterine growth restriction

sudden infant death syndrome

another $30 \%$ are passively exposed to cigarette smoke [33]. Data from the United States shows that from 6 to 30\% of pregnancies complicated with asthma are also complicated by active smoking [12]. Another study found more smokers among the group of pregnant women with asthma than among pregnant women without asthma [6].

Smoking causes many well recognised pregnancy complications [32] (Tab. 7); moreover, in pregnant women with asthma, it increases the risk of severe exacerbation and risk of urinary tract infection and pre-term birth [34].

A few studies examined the influence of atopy on the course of asthma in pregnancy. The research of Stenius-Aarniala, from 1988, found a more frequent occurrence of exacerbations in non-atopic asthma.

\section{Other factors}

Some minor factors may also contribute to a worsening of asthma control during pregnancy or may additionally burden pregnancy.

The influence of psychological stress on the occurrence of exacerbations during pregnancies with asthma has been investigated in many studies. Some of them indicate that anxiety, and a perception by the patient of the asthma as being uncontrolled, may influence exacerbations and be a risk factor for a cesarean section. A more frequent occurrence of depression in pregnancies complicated by asthma exacerbations was confirmed by the Tata research, citated by Murphy [6].

However, some factors are found to be questionable.

No association was found between GERD and asthma severity during pregnancy. A possible reason for this phenomenon may be related to an equal frequency in the presentation of GERD in pregnant and non-pregnant populations [35].

A few studies have suggested that fetal sex influences the course of asthma during pregnancy, with the course of asthma worsening with a female fetus. However, the data is inconsistent.

\section{Education}

Many guidelines point out the importance of education in asthma management and control [13]. This may be even more 
important during pregnancy, as up to $80 \%$ of female patients attempting to conceive are concerned about the influence of therapy on the fetus, and up to $40 \%$ cease treatment without consultation with a doctor. Pre-conceptional education, with an emphasis on treatment and symptoms of uncontrolled asthma, may play an important role in asthma management [6].

\section{Summary}

Management of asthma during pregnancy remains a challenge in everyday practice. The essentials of good asthma management include proper education and active treatment of patients. Frequent and accurate monitoring is vital to prevent, detect and treat exacerbations, and other conditions influencing the course of asthma. Gaining and maintaining good asthma control may prevent adverse perinatal outcomes for both mother and baby.

\section{Funding}

The research was funded by Medical University of Gdańsk, grant no. ST554.

\section{REFERENCES}

1. Rogala B. Astma u kobiet $w$ ciąży. Alergologia Polska - Polish Journal of Allergology. 2015; 2(3): 94-98, doi: 10.1016/j.alergo.2015.07.001.

2. Wang G, Murphy VE, Namazy J, et al. The risk of maternal and placental complications in pregnant women with asthma: a systematic review and meta-analysis. J Matern Fetal Neonatal Med. 2014; 27(9): 934-942, doi: 10.3109/14767058.2013.847080, indexed in Pubmed: 24111742.

3. Ali Z, Nilas L, Ulrik CS. Low risk of adverse obstetrical and perinatal outcome in pregnancies complicated by asthma: A case control study. Respir Med. 2016; 120: 124-130, doi: 10.1016/j.rmed.2016.10.004, indexed in Pubmed: 27817809.

4. Kelly W, Massoumi A, Lazarus A. Asthma in pregnancy: Physiology, diagnosis, and management. Postgrad Med. 2015; 127(4): 349-358, doi: 10.1080/00325481.2015.1016386, indexed in Pubmed: 25702799.

5. Fal A. Alergia, choroby alergiczne, astma [Allergy, allergic diseases, asthma]. MP, Kraków 2010: 423-430.

6. Robijn AL, Murphy VE, Gibson PG, et al. Asthma in pregnancy. Clin Chest Med. 2011; 32(1): 93-110, doi: 10.1016/j.ccm.2010.10.001, indexed in Pubmed: 21277452

7. Tamási $\mathrm{L}$, Horváth I, Bohács $\mathrm{A}$, et al. Asthma in pregnancy - Immunological changes and clinical management. Respiratory Medicine. 2011; 105(2): 159-164, doi: 10.1016/j.rmed.2010.11.006.

8. Minerbi-Codish I, Fraser D, Avnun L, et al. Influence of asthma in pregnancy on labor and the newborn. Respiration. 1998; 65(2): 130-135, doi: 10.1159/000029244, indexed in Pubmed: 9580925.

9. Murphy VE, Clifton VL, Gibson PG. Asthma exacerbations during pregnancy: incidence and association with adverse pregnancy outcomes. Thorax. 2006; 61(2): 169-176, doi: 10.1136/thx.2005.049718, indexed in Pubmed: 16443708.

10. Garne E, Hansen AV, Morris J, et al. Use of asthma medication during pregnancy and risk of specific congenital anomalies: A European case-malformed control study. J Allergy Clin Immunol. 2015; 136(6): 1496-1502.e7, doi: 10.1016/j.jaci.2015.05.043, indexed in Pubmed: 26220526.

11. Murphy VE, Wang G, Namazy JA, et al. A meta-analysis of adverse perinatal outcomes in women with asthma. BJOG. 2011; 118(11): 1314-1323, doi: 10.1111/j.1471-0528.2011.03055.x, indexed in Pubmed: 21749633.

12. Morten $M$, Collison A, Murphy VE, et al. Managing asthma in pregnancy. Breathe (Sheff). 2015; 11(4): 258-267, doi: 10.1183/20734735.007915, indexed in Pubmed: 27066119.

13. Global Initiative for Asthma. www.ginasthma.com (20.03.2019).

14. Cooper BG, Cooper BG. An update on contraindications for lung function testing. Thorax. 2011; 66(8): 714-723, doi: 10.1136/thx.2010.139881, indexed in Pubmed: 20671309.
15. Zairina E, Abramson MJ, McDonald CF, et al. A prospective cohort study of pulmonary function during pregnancy in women with and without asthma. J Asthma. 2016; 53(2): 155-163, doi: 10.3109/02770903.2015.1080268, indexed in Pubmed: 26365313.

16. Powell H, Murphy VE, Taylor DR, et al. Management of asthma in pregnancy guided by measurement of fraction of exhaled nitric oxide: a double-blind, randomised controlled trial. Lancet. 2011; 378(9795): 983-990, doi: 10.1016/S0140-6736(11)60971-9, indexed in Pubmed: 21907861.

17. Eltonsy S, Kettani FZ, Blais L. Beta2-agonists use during pregnancy and perinatal outcomes: a systematic review. Respir Med. 2014; 108(1): 9-33, doi: 10.1016/j.rmed.2013.07.009, indexed in Pubmed: 24360293.

18. Eltonsy S, Forget A, Beauchesne MF, et al. Risk of congenital malformations for asthmatic pregnant women using a long-acting $\beta_{2}$-agonist and inhaled corticosteroid combination versus higher-dose inhaled corticosteroid monotherapy. J Allergy Clin Immunol. 2015; 135(1): 123-130, doi: 10.1016/j.jaci.2014.07.051, indexed in Pubmed: 25226849.

19. Blais $L$, Beauchesne MF, Lemière $C$, et al. High doses of inhaled corticosteroids during the first trimester of pregnancy and congenital malformations. J Allergy Clin Immunol. 2009; 124(6): 1229-1234.e4, doi: 10.1016/j. jaci.2009.09.025, indexed in Pubmed: 19910032.

20. Gregersen TL, Ulrik CS. Safety of bronchodilators and corticosteroids for asthma during pregnancy: what we know and what we need to do better. J Asthma Allergy. 2013; 6: 117-125, doi: 10.2147/JAA.S52592, indexed in Pubmed: 24259987.

21. Bakhireva LN, Jones KL, Schatz $M$, et al. Organization of Teratology Information Specialists Collaborative Research Group. Safety of leukotriene receptor antagonists in pregnancy. J Allergy Clin Immunol. 2007; 119(3): 618-625, doi: 10.1016/j.jaci.2006.12.618, indexed in Pubmed: 17336611.

22. Namazy JA, Blais L, Andrews EB, et al. The Xolair Pregnancy Registry (EXPECT): the safety of omalizumab use during pregnancy. J Allergy Clin Immunol. 2015; 135(2): 407-412, doi: 10.1016/j.jaci.2014.08.025, indexed in Pubmed: 25441639.

23. Zetstra-van derWoude PA, Vroegop JS, Bos HJ, et al. A population analysis of prescriptions for asthma medications during pregnancy. J Allergy Clin Immunol. 2013; 131(3): 711-717, doi: 10.1016/j.jaci.2012.08.027, indexed in Pubmed: 23063582.

24. Kuczkowski KM. Labor analgesia for the parturient with respiratory disease: what does an obstetrician need to know? Arch Gynecol Obstet. 2005;272(2): 160-166, doi: 10.1007/s00404-004-0703-1, indexed in Pubmed: 15650837.

25. Lim A, Hussainy S, Abramson M. Asthma drugs in pregnancy and lactation. Australian Prescriber. 2013; 36(5): 150-153, doi: 10.18773/austprescr.2013.061.

26. Toxicology data network. https://toxnet.nlm.nih.gov/ (27.06.2019).

27. Merlob $P$, Weber-Schöndorfer $C$. Antiallergics, antiasthmatics and antitussives. Drugs During Pregnancy and Lactation. 2015: 671-676, doi: 10.1016/b978-0-12-408078-2.00027-5.

28. Ali Z, Nilas L, Ulrik CS. Determinants of low risk of asthma exacerbation during pregnancy. Clin Exp Allergy. 2018; 48(1): 23-28, doi: 10.1111/cea.13033, indexed in Pubmed: 28925525.

29. Blais $L$, Kettani FZ, Forget $A$, et al. Asthma exacerbations during the first trimester of pregnancy and congenital malformations: revisiting the association in a large representative cohort. Thorax. 2015; 70(7): 647-652, doi: 10.1136/thoraxjnl-2014-206634, indexed in Pubmed: 25888364.

30. Jain S, Kamimoto L, Bramley AM, et al. 2009 Pandemic Influenza A (H1N1) Virus Hospitalizations Investigation Team. Hospitalized patients with 2009 H1N1 influenza in the United States, April-June 2009. N Engl J Med. 2009; 361(20): 1935-1944, doi: 10.1056/NEJMoa0906695, indexed in Pubmed: 19815859.

31. Rastogi D, Wang C, Lendor C, et al. T-helper type 2 polarization among asthmatics during and following pregnancy. Clin Exp Allergy. 2006; 36(7): 892-898, doi: 10.1111/j.1365-2222.2006.02519.x, indexed in Pubmed: 16839404.

32. Andres RL, Day MC. Perinatal complications associated with maternal tobacco use. Semin Neonatol. 2000; 5(3): 231-241, doi: 10.1053/siny. 2000.0025, indexed in Pubmed: 10956448.

33. Balwicki $\measuredangle$, Zarzeczna-Baran $M$, Wierucki $\measuredangle$, et al. Smoking among pregnant women in small towns in Poland. Int J Public Health. 2016; 61(1): 111-118, doi: 10.1007/s00038-015-0735-2, indexed in Pubmed: 26337556.

34. Hodyl NA, Stark MJ, Scheil W, et al. Perinatal outcomes following maternal asthma and cigarette smoking during pregnancy. Eur Respir J. 2014;43(3): 704-716, doi: 10.1183/09031936.00054913, indexed in Pubmed: 23900987.

35. Bidad K, Heidarnazhad H, Pourpak Z, et al. Gastroesophageal Reflux Disease and Asthma in Pregnant Women with Dyspnea. 2014; 13: 104-1099. 